\title{
Chemical composition of essential oil extracted from leaves of Campomanesia adamantium subjected to different hydrodistillation times
}

\author{
Juliana Dantas de Oliveira ${ }^{1}$ Daniely Karen Matias Alves ${ }^{1}$ Mayker Lazaro Dantas Miranda ${ }^{2}$ \\ José Milton Alves ${ }^{1}$ Marcelo Nogueira Xavier ${ }^{1}$ Cristiane de Melo Cazal $^{3}$ \\ Cassia Cristina Fernandes Alves ${ }^{*}$
}

\author{
${ }^{1}$ Instituto Federal de Educação, Ciência e Tecnologia Goiano, Avenida Goiânia, Km 1, Zona Rural, 75901-970, Rio Verde, GO, Brasil. E-mail: \\ cassiacefetrv@gmail.com. *Corresponding author. \\ ${ }^{2}$ Instituto Federal de Educação, Ciência e Tecnologia do Sul de Minas Gerais, Pouso Alegre, MG, Brasil. \\ ${ }^{3}$ Instituto Federal de Educação, Ciência e Tecnologia do Sudeste de Minas Gerais, Barbacena, MG, Brasil.
}

\begin{abstract}
Campomanesia adamantium is a native fruit species of the Cerrado and is used in food and medicines and as bee pasture. The chemical composition of essential oils obtained from plants of the same species have varying constituent proportions due to the influence of extractive factors, environmental, genetic and ontogenetic. This study aimed to identify the influence of hydrodistillation time on the content and chemical composition of essential oil extracted from the leaves of $\boldsymbol{C}$. adamantium. Treatments consisted of five extraction times (1, 2, 3, 4, and 5h) using Clevenger with five replications in a completely randomized design. It was observed that after two hours of hydrodistillation, the essential oil content remains constant. Regarding the chemical constituents of essential oil, variation of the proportions of the compounds tested occurred at all hydrodistillation times. The compounds spathulenol oxygenated sesquiterpenes and caryophyllene oxide were the majority in the five hydrodistillation times.
\end{abstract}

Key words: essential oil, hydrodistillation time, sesquiterpenes.

Composição química do óleo essencial de Campomanesia adamantium extraído de folhas submetidas a diferentes tempos de hidrodestilação

RESUMO: A Campomanesia adamantium é uma espécie frutifera nativa do Cerrado que se destaca pela utilização na alimentação, na medicina e como pasto apícola. A composição química dos óleos essenciais obtidos de plantas de uma mesma espécie pode sofrer variação de seus constituintes por influência de vários fatores incluindo o método de extração do óleo essencial, fatores ambientais, genéticos e ontogenéticos. Neste sentido, o presente trabalho tem como objetivo identificar a influencia do tempo de hidrodestilação sobre o teor e a composição química do óleo essencial das folhas de $\boldsymbol{C}$. adamantium. Os tratamentos constituíram-se de cinco tempos de extração (1, 2, 3, 4 e 5 horas) utilizando aparelho Clevenger com cinco repetições, sendo o delineamento inteiramente casualizado. Foi observado que após duas horas de hidrodestilação o teor de óleo essencial permanece constante. Em relação aos constituintes químicos do óleo essencial ocorreu variação das proporções dos compostos em todos os tempos de hidrodestilação testados, os compostos sesquiterpenos oxigenados espatulenol e óxido cariofileno foram majoritários nos cinco tempos de hidrodestilação.

Palavras-chave: óleo essencial, tempo de hidrodestilação, sesquiterpenos.

\section{INTRODUCTION}

Campomanesia adamantium, commonly known as "gabiroba" or "guabiroba", is a deciduous shrub between 0.5 and $1.5 \mathrm{~m}$ high that flowers between September and October, and fructification between November and December (LORENZI et al., 2006).

C. adamantium belongs to the Myrtaceae family, which comprises approximately 4,000 species and 130 genera distributed across all continents, except Antarctica (D'ANGELIS et al., 2014). Its fruits are tasty, juicy, citric, and slightly sweet, constituting a very good aliment, and are consumed in natura in the food industry and as flavoring agents in the beverage industry, liquors, juices, sweets, and ice cream (VIEIRA et al., 2011).

Leaves and fruits of $\boldsymbol{C}$. adamantium have some medicinal properties, including antiinflammatory, antidiarrheal, and antiseptic properties in the urinary tract. Leaves are utilized to treatflu, and fruits act on the intestine. The alcoholic extract of $\boldsymbol{C}$. adamantium leaves, when tested, presented vasorelaxing activity on aortic rings isolated from mice (VIEIRA et al., 2011).

Studies on $\boldsymbol{C}$. adamantium provided data for the identification of chemical compounds 
found in its essential oil, leaf extracts, and fruit extracts, as well as forits pharmacology. However, no studies mention factors that may affect the content and chemical composition of essential oil extracted from gabiroba.

COUTINHO et al., (2009) identified 95 compounds in essential oils extracted from $\boldsymbol{C}$. adamantium leaves. During flowering, the major substances found were monoterpenes (limonene, $\alpha$-pinene, and $\beta$-pinene), while during the vegetative state, the predominant substances were sesquiterpenes (bicyclogermacrene and globulol). When hexane and ethyl acetate extracts from $\boldsymbol{C}$. adamantium leaves were evaluated, little variation was observed between their chemical compositions during plant development in different seasons, whereas the alcoholic extract had a significantly altered chemical composition (COUTINHO et al., 2010). When the biological activities of these organic extracts from $\boldsymbol{C}$. adamantium were evaluated, they showed promising cytotoxic and antioxidant activities (RAMOS et al., 2007).

COUTINHO et al., (2008a) isolated five flavanones and three chalcones from $\boldsymbol{C}$. adamantium leaves using HPLC. Extracts were obtained from leaves of this species harvested in four cities in Mato Grosso do Sul State, Brazil, revealing different amounts of total phenolic compounds and antioxidant activity. In another study performed with essential oil from its leaves and flowers, the chemical composition of volatile compounds from $\boldsymbol{C}$. adamantium were determined: limonene was the major compound $(21.9 \%)$ in essential oil from leaves, while ledol was the major compound $(20.9 \%)$ in essential oil from flowers (COUTINHO et al., 2008b).

VALLILO et al., (2006) evaluated $\boldsymbol{C}$. adamantium fruits harvested at different ripening stages, regardingto nutritional composition, essential oil profile, and the presence of organic substances. C. adamantium fruits presented an essential oil with a yellow color, and, through GC-MS analysis, 40 compounds were identified in the essential oil, corresponding to $93.3 \%$ of the compounds present. The major compounds reported in this essential oil were the monoterpene hydrocarbons $\alpha$-pinene $(10.6 \%)$, limonene (10.1\%), and $\beta$-(z)-ocimene $(9.2 \%)$.

According to the International Standard Organization (ISO), essential oils are defined as products obtained from plant tissue through steam distillation, as well as products obtained by pressing the pericarp of citrus fruits (NOGUEIRA et al., 2007).

Several international groups commercialize essential oils, many of which are used as raw materials in the production of flavors and fragrances. Brazil has an important role in the production of essential oils, and, together with India, China, and Indonesia, isamong the four biggest producers in the world. Brazil's position in this ranking is a result of the essential oils obtained from Citrus as by products of the juice industry (BIZZO et al., 2009).

The importance of studies with essential oils results from the fact that they present several biological activities reported in the literature, used, for instance, in the control of phytopathogens responsible for plant diseases that lead to significant production losses, grain destruction during storage, loss of nutritional value, and, occasionally, the production of mycotoxins that are harmful to human beings and animals. Approximately $60 \%$ of essential oils present antifungal activity and $35 \%$ show antibacterial properties (SANTOS et al., 2010).

According to OLIVEIRA et al., (2012), some aspects influence the chemical composition of essential oils, such as genetic and environmental factors, and others affect the yield, such as method and extraction time. These aspects indicated the importance of a previous evaluation of essential oil extraction time for each plant species analyzed, taking into account the particularities of the chemical compositions of the essential oils, and the extraction methods employed to obtain them, in order to promote an optimization of the whole process.

Studies concerning the influence of extraction time on the yield and chemical compositions of essential oils are scarce, though fundamental for the maximization of essential oil yield. In this context, the present research aimed to evaluate the effect of different hydrodistillation times on the content and chemical composition of essential oil extracted from $C$. adamantium .

\section{MATERIALS AND METHODS}

\section{Material harvest and selection}

C. adamantium leaves were harvested in the Rio Verde region between 7 and 8 a.m., on October $10^{\text {th }}, 2014$, atproperties belonging to the University of Rio Verde (coordinates, $17^{\circ} 47^{\prime} 14.8^{\prime \prime}$, W 50 57'59.1'; altitude, $769 \mathrm{~m}$ ). The plant material was identified by Professor Germano Guarin Neto Herbarium (Jataí, Brazil) according to Voucher HJ 6561. The leaves were then taken to the Laboratory of Chemistry and Natural Products for essential oil extraction.

\section{Essential oil extraction}

Essential oil extraction from gabiroba leaves $(400 \mathrm{~g})$ in natura was performed via a 
hydrodistillation method using a Clevenger apparatus, in a process similar to that employed by SIQUEIRA et al., (2011). Extractions were carried out at five different time lengths $(1,2,3$, 4 , and $5 \mathrm{~h}$ ) after ebullition, with five repetitions each. Following the five different hydrodistillation times, essential oil was extracted from the aqueous phase by partition with an organic solvent (dichloromethane) in three successive repetitions of $10 \mathrm{~mL}$ each, and a resting time of $10 \mathrm{~min}$ between them in order to ensure phase separation. Anhydrous sodium sulfate was used to remove traces of water from the resulting mixture consisting of essential oil/dichloromethane, which was subsequently filtered. After the complete evaporation of the dichloromethane, the extracted essential oil was weighed using an analytical scale and stored at $-4^{\circ} \mathrm{C}$ until analysis by GC-MS.

\section{Essential oil chemical analysis}

The essential oil was diluted in hexane and analyzed by gas phase chromatography (QP-5000 da Shimadzu ${ }^{\circledR}$ ) for detection via mass spectrometry (GC-MS). The evaluation was performed in a fused silica capillary column model DB-5 (30m length x $0.25 \mathrm{~mm}$ inner diameter $\mathrm{x} 0.25 \mu \mathrm{m}$ film thickness) $\left(\right.$ Shimadzu $\left.^{\circledR}\right)$. Helium $(\mathrm{He})$ was used as the carrier gas with a flow of $1.0 \mathrm{~mL} / \mathrm{min}$. The 1:20 split injection was performed using an injector at $240^{\circ} \mathrm{C}$. The temperature of the detector was $270^{\circ} \mathrm{C}$, and the oven was programmed to heat from 60 to $180^{\circ} \mathrm{C}$ at a rate of $3{ }^{\circ} \mathrm{C} / \mathrm{min}$. Detection was performed in electron ionization mode at $70 \mathrm{e} \mathrm{V}$. Three repetitions were performed for each essential oil analyzed. Essential oil chemical composition was determined based on the mass spectra acquired by GC-MS. Volatile compounds were identified by comparing the retention times achieved in the experiment with the retention times of linear hydrocarbons $\left(\mathrm{C}_{10}-\mathrm{C}_{29}\right.$ homologous series), which were co-injected with the sample of interest. The retention rates and the mass spectra were compared with data from the spectral library of Wiley, Nist, and other literature (ADAMS, 2007).

\section{Statistical analysis}

A completely randomized design (CRD) was used in the experiment, with five hydrodistillation times (1, 2, 3, 4, and 5h) and five repetitions each. The results were statistically analyzed using an analysis of variance $(\mathrm{F}<0.05)$ and the averages were compared using the Tukey's test at a 5\% significance level with the software ASSISTAT version 7.7 beta.

\section{RESULTS AND DISCUSSION}

To evaluate the effect of hydrodistillation time on the content and chemical composition of essential oils from $\boldsymbol{C}$. adamantium leaves, several extractions were performed at different times, with the purpose of gathering information on the behavior of this species harvested at certain times and locations regarding the hydrodistillation time.

Figure 1 shows the content of essential oil extracted from $\boldsymbol{C}$. adamantium leaves asa function of hydrodistillation time. After $1 \mathrm{~h}$ of extraction, it was observed that the essential oil content was $0.18 \%$, a value statistically lower than the amounts obtained at all other hydrodistillation times. After $2 \mathrm{~h}$, the essential oil content was $0.31 \%$, after which longer hydrodistillation times did not result in statistically different amounts of essential oil; hydrodistillation for $3 \mathrm{~h}, 4 \mathrm{~h}$, and $5 \mathrm{~h}$, resulted in contents of $0.29 \%, 0.30 \%$, and $0.32 \%$, respectively. The results obtained for $\boldsymbol{C}$. adamantium were similar to those found by OLIVEIRA et al.,(2012), who, after hydrodistillation for $2 \mathrm{~h}$ in a Clevenger apparatus, was able to extract $0.5 \mathrm{~mL}$ of essential oil from the leaves of mint plants, with stabilization of the extracted volume. According to SILVA et al., (2003), essential oil contents are affected by different relative humidity and temperature, even on the same day. Therefore, knowledge of the ideal hydrodistillation time in order to extract higher concentrations of active principles would be of fundamental importance when taking decisions on chemical and agronomical aspects of production.

When comparing the variation in essential oil yields observed in the present work, with the results from related studies, it was observed that there was indeed a large variation in essential oil yield according to the species, the method, and, time of extraction. Different methods and extraction times for essential oil from Peruvian pepper (Schinus molle L.) were also analyzed, and the authors observed that, in this species, the yield of essential oil extracted by hydrodistillation was directly proportional to the extraction time $(4 \mathrm{~h} / 4.61 \%)$. They also concluded that hydrodistillation was the most efficient extraction method when compared to the infusion and soxhlet methods, since it yielded a greater number of chemical compounds (MATTANA et al., 2015).

The hydrodistillation time resulting in the highest content of essential oil from $\boldsymbol{C}$. adamantium leaves was similar to that found by EHLERT et al., (2006) for other medicinal plants: $130 \mathrm{~min}$ for Cymbopogon citratus; $150 \mathrm{~min}$ for Cymbopogon 




winterianus, Aristolochia sp., Hyptis pectinata, and Hyptis fruticosa; $160 \mathrm{~min}$ for Lippia sidoides; and 230min for Eucalyptus globulus.

The variation in chemical composition of essential oil extracted from $\boldsymbol{C}$. adamantium leaves when subjected to different hydrodistillation times is presented on table 1. Chemical analyses enabled the identification of 36 compounds after $1 \mathrm{~h}$ of hydrodistillation. At other hydrodistillation times, the amount of compounds decreased, and, according to SIMÕES et al., (2007), the essential oils may have low stability in the presence of light, heat, air, and humidity. These factors may have affected the relative amounts of the compounds. Analysis of the chemical composition of the essential oil is studied based on relative ratio, not the molecular weights of the substance in the essential oil, increasing the proportion of other substances as time may result in the decrease of others. Another factor that may also be occurred is the breakdown of these substances, but more studies are needed (MATTANA et al., 2015).

According to STEFANELLO et al., (2010), compounds with relative amounts higher than $8 \%$ were considered major components. Therefore, the major compounds found at all hydrodistillation times $(1,2,3,4,3$, and $5 \mathrm{~h})$ were the oxygenated sesquiterpenes spathulenol (11.50-20.66\%)and caryophyllene oxide (10.03-14.42\%). These findings were similar to those achieved by LIMBERGERet al., (2001), who, when chemically analyzing essential oil from the leaves of Campomanesia species, observed the prevalence of sesquiterpenes spathulenol (27.7\%) and $\beta$-caryophyllene oxide $(29.0 \%)$ in $\boldsymbol{C}$. guazumifolia; bicyclogermacrene (13.6\%) and globulol (10.8\%) in C. rombea, and E-nerolidol $(28.8 \%)$ in C. xanthocarpa.

The highest occurrence of spathulenol $(20.66 \%)$ and caryophyllene oxide $(14.42 \%)$ was observed after hydrodistillation for $1 \mathrm{~h}$. Therefore,the concentration of oxygenated compounds from this species at the beginning of the extraction process reduced as the hydrodistillation time increased. This observation may result from the hydrofusion effect, i.e., a higher solubility of those molecules in water (MATTANA et al., 2015).

Variations in relative proportions were also observed for sesquiterpene hydrocarbon germacrene $\mathrm{B}$, which produced higher 
Chemical composition of essential oil extracted from leaves of Campomanesia adamantium subjected to different hydrodistillation... 5

Table 1 - Substances identified in essential oil from leaves of gabiroba subjected to five different hydrodistillation times.

\begin{tabular}{|c|c|c|c|c|c|c|c|}
\hline \multirow{3}{*}{ Substances } & \multirow{3}{*}{$\mathrm{RI}_{\text {lit }}$} & \multirow{3}{*}{$\mathrm{RI}_{\text {exp }}$} & \multicolumn{5}{|c|}{---------------------------Hydrodistillation time (hours)------------------------ } \\
\hline & & & 1 & 2 & 3 & 4 & 5 \\
\hline & & & \multicolumn{5}{|c|}{ - } \\
\hline$\alpha$-Pinene & 917 & 926 & - & 0.35 & - & - & - \\
\hline$\beta$-Pinene & 952 & 954 & 0.28 & 2.30 & 1.59 & 0.50 & 1.08 \\
\hline Ocimene & 987 & 988 & 0.15 & - & 0.24 & 0.06 & - \\
\hline D-Limonene & 995 & 991 & 0.48 & - & 0.51 & 0.19 & 0.51 \\
\hline Eucalyptol & 997 & 994 & 0.25 & - & 0.25 & 0.08 & - \\
\hline Linalool & 1060 & 1053 & 4.00 & 4.09 & 3.16 & 3.16 & 1.52 \\
\hline Fenchol & 1063 & 1067 & 0.22 & - & - & 0.15 & - \\
\hline L-Pinocarveol & 1083 & 1091 & 0.10 & - & - & - & - \\
\hline Camphol & 1120 & 1118 & 0.51 & - & 0.40 & 0.30 & - \\
\hline Terpinen-4-ol & 1200 & 1130 & 0.29 & - & 0.15 & 0.18 & 0.77 \\
\hline$\alpha$-Terpineol & 1135 & 1144 & 1.76 & 1.55 & 1.42 & 1.21 & - \\
\hline Myrtenol & 1148 & 1150 & 0.15 & - & - & - & - \\
\hline$\alpha$-Copaene & 1376 & 1379 & 1.35 & 1.02 & 1.03 & 1.09 & 1.46 \\
\hline$\beta$-Elemene & 1358 & 1356 & 0.37 & - & 0.98 & 0.92 & 0.72 \\
\hline$\alpha$-Gurjunene & 1395 & 1374 & 0.16 & - & - & 0.18 & - \\
\hline$\beta$-Caryophyllene & 1382 & 1384 & 8.92 & 8.23 & 5.80 & 6.01 & 15.7 \\
\hline Isoledene & 1373 & 1394 & 0.20 & - & - & 0.33 & 0.26 \\
\hline 3,7(11)-Selinadiene & 1400 & 1400 & 0.05 & - & - & - & - \\
\hline Aromadendrene & 1410 & 1404 & 2.65 & 2.67 & 3.77 & 3.96 & 2.17 \\
\hline Humulene & 1418 & 1419 & 2.18 & 1.70 & 1.47 & 1.49 & 2.91 \\
\hline Alloaromadendrene & 1427 & 1427 & 2.15 & 2.07 & 2.37 & 2.26 & 1.64 \\
\hline$\gamma$-Muurolene & 1475 & 1443 & 0.75 & - & 0.83 & 0.99 & 1.14 \\
\hline$\beta$-Copaene & 1448 & 1447 & 1.78 & 4.52 & 3.18 & 1.89 & 4.89 \\
\hline$\beta$-Eudesmene & 1458 & 1453 & 0.21 & - & 0.33 & 0.18 & 0.17 \\
\hline Germacrene B & 1460 & 1464 & 5.19 & 16.80 & 18.27 & 9.30 & 10.8 \\
\hline$\alpha$-Muurolene & 1467 & 1467 & 0.71 & 0.68 & 0.72 & 0.82 & 1.23 \\
\hline$\gamma$-Cadinene & 1472 & 1481 & 0.96 & 0.87 & 0.92 & 1.02 & 1.23 \\
\hline$\delta$-Cadinene & 1492 & 1490 & 0.94 & 1.43 & 1.74 & 1.42 & 2.45 \\
\hline Viridiflorene & 1505 & 1504 & 0.25 & - & - & - & - \\
\hline Guaia-1(10),11-diene & 1530 & 1523 & 0.07 & - & - & 0.16 & - \\
\hline Epiglobulol & 1527 & 1525 & 0.28 & - & - & 0.37 & 0.22 \\
\hline Spathulenol & 1548 & 1544 & 20.66 & 16.27 & 15.04 & 19.27 & 11.5 \\
\hline Caryophyllene oxide & 1552 & 1550 & 14.42 & 10.19 & 10.03 & 12.37 & 12.2 \\
\hline Viridiflorol & 1557 & 1557 & 3.28 & 3.75 & 4.17 & 4.98 & 12.2 \\
\hline Guaiol & 1560 & 1559 & 1.23 & 1.49 & 1.81 & 1.99 & 1.52 \\
\hline Cubedol & 1580 & 1592 & 0.46 & - & - & - & 0.37 \\
\hline$\delta$-Cadinol & 1600 & 1605 & 1.70 & 2.17 & - & - & - \\
\hline$\alpha$-Cadinol & 1618 & 1617 & 2.59 & 2.84 & - & - & - \\
\hline Monoterpenes & & & 8.19 & 8.29 & 7.72 & 5.83 & 3.88 \\
\hline Sesquiterpenes & & & 73.51 & 76.70 & 72.46 & 71.00 & 84.8 \\
\hline Total compounds & & & 37 & 16 & 17 & 21 & 20 \\
\hline
\end{tabular}

$\mathrm{RI}_{\text {lit }}$ : Retention index from the literature. $\mathrm{RI}_{\text {exp }}$ : Retention index determined relative to n-alkanes $\left(\mathrm{C}_{10}-\mathrm{C}_{29}\right)$ on the DB-5 column. \%RA: Relative area (peak area relative to the total peak in the GC-MS chromatogram), average of three replicates.

concentrations at hydrodistillation times of 2, 3, 4 , and $5 \mathrm{~h}$. The oxygenated sesquiterpene viridiflorol showed a higher concentration at a hydrodistillation time of 5 h. Another compound that had varying relative amounts was sesquiterpene hydrocarbon $\beta$-caryophyllene, with higher concentrations at the following hydrodistillation times: $1 \mathrm{~h}(8.92 \%), 2 \mathrm{~h}(8.23 \%)$, and $5 \mathrm{~h}(15.72 \%)$, due to the non-polar profile of its molecule.

There were indications that the extraction time affected the amount of each 
substance extracted; however,specific studies are still needed, such as performance of the calibration curve for each compound using molecular patterns or molecule stability assays.

CHATZOPOULOU\& KATSIOTIS (1995) and PRINS et al., (2006) evaluated the effect of extraction time on the chemical composition of the species Jenuperus communis L. and Rosmarinus officinalis L., respectively, and observed a tendency for the concentration of oxygenated compounds at the beginning of the extraction process, in accordance with the results achieved here in for the essential oil extracted from $\boldsymbol{C}$. adamantium leaves.

\section{CONCLUSION}

Despite the scarcity of studies related to this subject, it had already been shown that the yield of essential oils and relative proportion of their chemical substances varied according to the species, and the time and method of extraction employed. Nevertheless, there was still the need for information on the ideal method and time for essential oil extraction, so that there was concise data for each medicinal species, in order to provide trusted and precise results, allowing for the maximization of essential oil yield in all works involving extraction processes.

Under the experimental conditions, we conclude that the content and chemical composition of essential oil extracted from $\boldsymbol{C}$. adamantium leaves were significantly different depending on how long the plant material was subjected to hydrodistillation. After $2 \mathrm{~h}$ of hydrodistillation, the essential oil content stabilized, and the amount of major compounds present in the essential oil varied according to hydrodistillation time.

We identified oxygenated sesquiterpenes, such as spathulenol and caryophyllene oxide, as the major compounds present, regardless of hydrodistillation time. Considering the results of the present work, we can conclude that, for $\boldsymbol{C}$. adamantium, the essential oil extraction time directly affects the yield and the proportion of the chemical compounds present in the essential oil. In order to achieve the maximum essential oil yield from this species, it is recommended to use an extraction time of $2 \mathrm{~h}$, since longer times did not lead to different results.

\section{REFERENCES}

ADAMS, R.P. Identification of essential oil components by Gas Chromatography/ Mass Spectrometry. Illinois, Carol Stream, 2007, 4v.
BIZZO, H.R. et al.Brazilian essential oils: general view, developments and perspectives. Química Nova, v.32, n.3, p. 588-594, 2009. Available from: $<$ http://dx.doi.org/10.1590/S010040422009000300005>. Accessed: Nov. 30, 2015. doi: 10.1590/ S0100-40422009000300005.

CHATZOUPOULOU, P.S.; KATSIOTIS, S.T. Procedures influencing the yield and the quality of the essential oil from Juniperus communis (L.) berries. Pharmaceutica Acta Helvetica, n.70, p.247-253, 1995. Avaliable from: < http://dx.doi. org/10.1016/0031-6865(95)00026-6>. Accessed: Sept. 15, 2015. doi: 10.1016/0031-6865(95)00026-6.

COUTINHO, I.D. et al. Determination of phenolic compounds and evaluation of antioxidante capacity of Campomanesia adamantium leaves. Eclética Química, v.33, n.4, p.53-60, 2008a. Avaliable from: <http://dx.doi.org/10.1590/S010046702008000400007>. Accessed: Sept. 2, 2015. doi: 10.1590/ S0100-46702008000400007.

COUTINHO, I.D. et al.Identification of the volatile compounds of leaves and flowers in guavira (Campomanesia adamantium). Journal Essential Oil Research, v.20, n.5, p.405-407, 2008b. Avaliable from: <http://dx.doi.org/10.10 80/10412905.2008.9700041>. Accessed: Sept. 8, 2015. doi: 10.1080/10412905.2008.9700041.

COUTINHO, I.D. et al. Gas Chromatography-Mass Spectrometry (GC-MS) and evaluation of antioxidant and antimicrobial activities of essential oil of Campomanesia adamantium (Cambess.) O. Berg (Guavira). Brazilian Journal of Pharmaceutical Sciences,v.45, n.4, p. 767-776, 2009. Avaliable from: <http://dx.doi.org/10.1590/ S1984-82502009000400022>. Accessed: Aug. 2, 2015. doi: 10.1590/S1984-82502009000400022.

COUTINHO, I.D. et al. Influência da variação sazonal nos teores de flavonoides e atividade antioxidante das folhas de Campomanesia adamantium (Cambess.) O. Berg, Myrtaceae. Revista Brasileira de Farmacognosia, v.20, n.3, p.322-327, 2010. Avaliable from: <http://dx.doi.org/10.1590/S0102695X2010000300006>. Accessed: Aug. 28, 2015. doi: 10.1590/ S0102-695X2010000300006.

D'ANGELIS, A.S.R. et al. Pimenta pseudocaryophyllus (Gomes) Landrum: aspectos botânicos, ecológicos, etnobotânicos e farmacológicos. Revista Brasileira de Plantas Medicinais, v.16, n.3, p.607-617, 2014. Avaliable from: <http://dx.doi. org/10.1590/1983-084X/13 026>. Accessed: Aug. 28, 2015. doi: 10.1590/1983-084X/13_026.

EHLERT, P.A.D. et al. Tempo de hidrodestilação na extração de óleo essencial de sete espécies de plantas medicinais. Revista Brasileira de Plantas Medicinais, v.8, p.79-80, 2006. Accessed: Aug. 28, 2015.

LIMBERGER, R.P. et al. Chemical composition of essential oils from some Campomanesia species (Myrtaceae). Journal Essential Oil Research, v.13, n.2, p.113-115, 2001. Avaliable from: <http://dx.doi.org/10.1080/10412905.2001.9699630>. Accessed: Aug. 28, 2015. doi: 10.1080/10412905.2001.9699630.

LORENZI, H. et al. Frutas brasileiras e exóticas cultivadas (de consumo in natura). Nova Odessa-SP. Instituto Plantarum de Estudos da Flora, 2006, p. 178-190.

MATTANA, R.S. et al. Efeitos de diferentes tempos de extração no teor e composição química do óleo essencial de folhas 
de pariparoba [Pothomorphe umbellata (L.) Miq.]. Revista Brasileira de Plantas Medicinais, v.17, n.1, p.150-156, 2015. Avaliable from: <http://dx.doi.org/10.1590/1983-084X/09_119>. Accessed: Sept. 24, 2015. doi: 10.1590/1983-084X/09_119.

NOGUEIRA, M.T.D. Óleos essenciais: a normalização e a sua importância no âmbito do regulamento Reach. Lisboa, Portugal: Departamento de Tecnologia de Indústrias Químicas, Produtos Naturais, Instituto Nacional de Engenharia, Tecnologia e Inovação, 2007, 495 p.

OLIVEIRA, A.R.M.F. et al. Determinação do tempo de hidrodestilação e do horário de colheita no óleo essencial de menta. Horticultura Brasileira, v.30, p.155-159, 2012. Avaliable from: <http://dx.doi.org/10.1590/S010205362012000100026>. Accessed: Aug. 15, 2015. Doi: 10.1590/ S0102-05362012000100026.

PRINS, C.L.et al.Efeito do tempo de extração sobre a composição e o rendimento do óleo essencial de alecrim (Rosmarinus officinalis). Revista Brasileira de Plantas Medicinais, v. 8, n.4 p.92-95, 2006. Accessed: Aug. 15, 2015.

RAMOS, D.D. et al. Avaliação do potencial citotóxico e atividade antioxidante em Campomanesia adamantium (Cambess) O. Berg (Myrtaceae). Revista brasileira Biociências, v.5, p.774-776, 2007. Accessed: Aug. 15, 2015.

SANTOS, A.C.A. et al. Efeito fungicida dos óleos essenciais de Schinus molle L. eSchinus terebinthifolius Raddi, Anacardiaceae do Rio Grande do Sul. Revista Brasileira de Farmacognosia, v.20, n.2, p.154-159, 2010. Avaliable from: $<$ http://dx.doi. org/10.1590/S0102-695X2010000200003>. Accessed: Sept. 15, 2015. doi: 10.1590/S0102-695X2010000200003.
SILVA, S.R.S. et al. Análise dos constituintes químicos e da atividade antimicrobiana do óleo essencial de Melaleuca alternifolia Cheel. Revista Brasileira de Plantas Medicinais, v.6, p. 63-70, 2003. Accessed: Sept. 18, 2015.

SIMÕES, C.M. et al. Farmacognosia: da planta ao medicamento 6 ed, Porto Alegre, UFRGS, 2007, p. 45.

SIQUEIRA, C.A.T. et al. Chemical constituents of the volatile oil from leaves of Annona coriácea and in vitro antiprotozoal activity. Revista Brasileira de Farmacognosia, v.21, n.1, p.3340, 2011. Avaliable from: <http://dx.doi.org/10.1590/S0102695X2011005000004>. Accessed: Dec. 3, 2015. doi: 10.1590/ S0102-695X2011005000004.

STEFANELLO, M.E.A. et al. Composição e variação sazonal do óleo essencial de Myrcia obtecta (O. Berg) Kiaersk. var. obtecta, Myrtaceae. Revista Brasileira de Farmacognosia, v.20, n.1, p.82-86, 2010. Avaliable from: <http://dx.doi.org/10.1590/S0102695X2010000100017>. Accessed: Dec. 3, 2015. doi: 10.1590/ S0102-695X2010000100017.

VALLILO, M.I. et al. Identificação de terpenos no óleo essencial dos frutos de Campomanesia adamantium (Cambessédes) O. Berg - Myrtaceae. Revista do Instituto Florestal, v.18, p.15-22, 2006. Accessed: Dec. 15, 2015.

VIEIRA, M.C. et al. Nitrogênio e fósforo no desenvolvimento inicial da guavira [Campomanesia adamantium (Cambess.) O. Berg] cultivada em vasos. Revista Brasileira de Plantas Medicinais, v.13, p.542-549, 2011. Avaliable from: $<$ http://dx.doi. org/10.1590/S1516-05722011000500007>. Accessed: Dec. 15, 2015. doi: 10.1590/S1516-05722011000500007. 